December 2010

\title{
Dilemmas of Teaching the "Greatest Silence": Rape-as-Genocide in Rwanda, Darfur, and Congo
}

Kimberly A. Ducey

Follow this and additional works at: https://digitalcommons.usf.edu/gsp

\section{Recommended Citation}

Ducey, Kimberly A. (2010) "Dilemmas of Teaching the "Greatest Silence": Rape-as-Genocide in Rwanda, Darfur, and Congo," Genocide Studies and Prevention: An International Journal: Vol. 5: Iss. 3: Article 7. Available at: https://digitalcommons.usf.edu/gsp/vol5/iss3/7

This Articles is brought to you for free and open access by the Open Access Journals at Digital Commons @ University of South Florida. It has been accepted for inclusion in Genocide Studies and Prevention: An International Journal by an authorized editor of Digital Commons @ University of South Florida. For more information, please contact digitalcommons@usf.edu. 


\title{
Dilemmas of Teaching the "Greatest Silence": Rape-as-Genocide in Rwanda, Darfur, and Congo
}

\author{
Kimberley A. Ducey \\ University of Winnipeg
}

The author describes the dilemmas of teaching about rape-as-genocide, focusing on Rwanda, Darfur, and Congo. While theoretically and methodologically sophisticated academic writings are a crucial part of the pedagogical approach described here, the author's focus is on the dilemmas associated with using testimonials and memoirs, documentaries, and commentaries. It is argued that such discourse helps make the subject matter more accessible to undergraduates. One of the key issues that arises from this discussion is students' preference for first-hand accounts. Excerpts from the students' writing dispersed throughout the article provide an essential and frank assessment of the importance of the approach described. The method of instruction encompasses pedagogical issues that cut across disciplines and will appeal to instructors in a broad range of fields. The author systematically analyzes students' written work for evidence of learning.

Key words: genocidal rape, Rwanda, Darfur, Congo, genocide, sexual violence, pedagogy

\section{Introduction}

The 1994 Rwanda Genocide is commonly referred to as the "machete genocide" because perpetrators systematically hacked their victims to death with machetes. Such descriptors are understandable and may encourage awareness of genocide; arguably, however, the number of dead becomes "the definitive measure of tragedy even though it may distance us from the human consequences of genocidal actions." 1

When my students hear the word "genocide," they usually do not think of mass rape methodically planned to wipe out an ethnic group-in whole or in part. They do not generally think of women deliberately infected with HIV in an orchestrated attempt to ensure that future sexual partners, and children of survivors, will be infected as well and ultimately killed by the disease. These matters get to the heart of the current article-the dilemmas of teaching about rape-as-genocide.

The approach described here is an effective tool for a pedagogical examination of traditional attitudes toward women that tacitly condone violence against women. It serves as a catalyst for discussions regarding the lingering effects of rape-as-genocide (e.g., survivors suffer severe stigma and discrimination, especially if they are also living with HIV; they frequently endure the denial of their rights to employment, property, and inheritance). Furthermore, this approach serves as a vehicle for discussions concerning social, political, and cultural climates in which women find it extremely difficult to speak openly about sexual violence or give testimony in court.

Kimberley A. Ducey, "Dilemmas of Teaching the "Greatest Silence': Rape-as-Genocide in Rwanda, Darfur, and Congo," Genocide Studies and Prevention 5, 3 (December 2010): 310322. (C) 2010 Genocide Studies and Prevention. doi:10.3138/gsp.5.3.310 
In Rwanda, for example, some survivors choose not to participate in the traditional gacaca courts because many rapists receive short sentences and are released back into the community in exchange for their confessions. ${ }^{2}$

While theoretically and methodologically sophisticated pedagogic discourse is a crucial part of my approach to teaching about rape-as-genocide, the current focus is on testimonials and memoirs, documentaries, and commentaries, which help make the subject matter more accessible to undergraduates. One of the key issues that arises from this discussion is students' preference for first-hand accounts. Excerpts from students' writing (including take-home exams, anonymous course evaluations, and personal correspondence via e-mail) dispersed throughout this article provide an essential and frank assessment of the importance of the approach described here.

From the outset, two caveats are in order. One, teaching about rape as a weapon of genocide is not viewed as a zero-sum game in which every word about male victimization automatically leads to one less word on female victimization or vice versa. Although sexual violence and rape are perpetrated against girls and boys, women and men, discussion in this article is largely limited to the experiences of girls and women. Two, it should be acknowledged that there are particular issues when dealing with victims of rape (in any context) regarding protection, the difficulty of giving evidence, and the need to avoid re-traumatization. ${ }^{3}$

\section{General Overview of the Course}

I include a unit on rape-as-genocide in an advanced sociology course on comparative genocide. An examination of several cases provides the foundation for comparative analysis, including Rwanda, Darfur, and Congo.

In addition to a unit on rape, topics include micro- and macro-level theories; the development of human rights in international law; the relationship between human rights and genocide; the history of the criminalization of genocide; and prevention and prosecution strategies (i.e., early warning systems, punishment as deterrence, the UN, the International Criminal Court, and the role of NGOs).

Topics are arranged in specific chronological order. Classic social psychological studies-including Stanley Milgram's obedience experiments and Philip Zimbardo's Stanford prison experiment-are introduced near the beginning of the course, helping students grasp how ordinary (wo)men become bystanders and even perpetrators of genocide. ${ }^{4}$

Ervin Staub's work is also studied early in the course as we contemplate not only how those in authority bring about compliance, but also how the motivation of the entire group evolves. Students are asked to grapple with Staub's (1989) conclusion that "Milgram's dramatic demonstration of the power of authority, although of great importance, may have slowed the development of a psychology of genocide, as others came to view obedience as the main source of human destructiveness."5

Students then familiarize themselves with the Goldhagen controversy, ${ }^{6}$ and in the process become acquainted with decades of research on the Holocaust conducted by such prominent scholars as Hannah Arendt, Omer Bartov, Martin Broszat, Christopher Browning, Saul Friedländer, Raul Hilberg, Herbert C. Kelman, Robert Jay Lifton, and Hans Mommsen. The course ends with theoretical insights on obstacles to reconciliation and discussions on how to prevent genocide.

\section{Unit on Rape-as-Genocide}

I recognize the necessity and value of theoretically sophisticated scholarly works, including the work of feminist legal scholars. ${ }^{7}$ Such discourse plays a pivotal role in 
my teaching. ${ }^{8}$ The stress on the theoretical ensures that the academic material students are supposed to learn is not sacrificed despite the prominence in my course of testimonials and memoirs, documentaries, and commentaries.

In this vein, Allison Reid-Cunningham's (2008) "Rape as a Weapon of Genocide" offers an invaluable introduction, including a brief history of sexual violence and rape in armed conflict and genocide; an overview of the scope of the current problem; the contextualization of sexual violence and rape in terms of social and cultural realities; the effects of rape, including infection, illness, injuries, pregnancy, psychosocial problems, and post-traumatic stress; and consequences for communities, including stigma, deterioration of family, and societal structures. An educator seeking an article to include in a lesson or unit on rape would almost certainly find this piece an ideal introduction for university and college students. ${ }^{9}$

For a focus on Sudan, Kelly Askin's (2006) "Holding Leaders Accountable in the International Criminal Court (ICC) for Gender Crimes Committed in Darfur" proves effective in focusing students' attention on how rape and other forms of sexual violence have been prominent features of the ongoing attacks committed by government of Sudan (GS) troops and the Janjaweed (Arab militia). Following a discussion of specific cases of rape and other sexual crimes committed in Darfur, Askin discusses how such crimes can be, and have been, prosecuted as war crimes, crimes against humanity, and genocide. Other topics discussed include concepts of individual and superior responsibility, and the need to hold leaders liable for sex crimes. ${ }^{10}$

\section{Human Rights and International Law}

Students are introduced to human rights legislation and supranational criminal law and procedure in the next part of the unit on rape-as-genocide. Anne-Marie de Brouwer's (2005) "Supranational Criminal Prosecution of Sexual Violence: The ICC and the Practice of the ICTY and the ICTR," 11 selections from Alexandra Stiglmayer's (1994) Mass Rape: The War Against Women in Bosnia-Herzegovina ${ }^{12}$ and Adam Jones' (2004) Gendercide and Genocide ${ }^{13}$ prove especially effective in providing a history of rape as a weapon of war and genocide. Moreover, de Brouwer, Stiglmayer, and Jones successfully raise the question of whether supranational criminal law and procedure are satisfactory from the perspective of victims of sexual violence. Consequently for students, a paramount question becomes whether sexual crimes against girls and women in Rwanda, Darfur, and Congo will fade from public and historical consciousness or survive as exceptional cases. After all, even where rape and forced prostitution is mass or systematic historically, as occurred in both arenas of World War II, or when cases have shaken the global conscious, such as in the "rape of Nanking," survivors do not characteristically obtain redress. Though the "rape of Nanking" was discussed in the judgment of the International Military Tribunal for the Far East (IMTFE) (1946-1948), also known as the Tokyo Trials or the Tokyo War Crimes Tribunal, rape was not separately charged against the Japanese commander as a crime. It was not until 1992, in the face of widespread rapes of women in the former Yugoslav Republic, that the issue of sexual violence in conflict finally came to the attention of the United Nations Security Council. ${ }^{14}$

The first international judicial body to recognize rape and sexual violence as genocide was the International Criminal Tribunal for Rwanda (ICTR). The ICTR was established by the United Nations Security Council in November 1994 with a mandate of judging those responsible for the genocide and other grave violations of international law. The inauguration of the ICTR was followed by the establishment of the permanent International Criminal Court (ICC) that came into effect on 1 July 
2002. In June 2008, the United Nations Security Council adopted UN Resolution 1820 , aimed at ending sexual violence in conflict.

\section{Testimonials and Memoirs: The Men Who Killed Me and Tears of the Desert}

The ability of first-hand accounts to bring another dimension to students' understanding of rape-as-genocide is unmistakable. In the absence of survivors as guest speakers, these narratives play a prominent role in my students' education. To this effect, in the case of Rwanda, I have found no better source than de Brouwer and Sandra Chu's (2009) The Men Who Killed Me. ${ }^{15}$

The testimonials of seventeen genocidal rape victims-sixteen women and one man $^{16}$ _as detailed in de Brouwer and Chu's work enhances students' understanding of rape-as-genocide. For example, students are stunned to learn that some Rwandan survivors still live within walking distance of those who committed violence against them. A student addresses this issue in her exam:

[In] the traditional gacaca courts Rwanda had prior to 2008, [they had] jurisdiction to deal with all crimes related to the genocide, except for crimes known as "category one crimes" (i.e., crimes committed by the planners and supervisors of the genocide, as well as rape and sexual torture). Category one crimes were intended to be prosecuted before national courts. However, the undertaking was so colossal that approximately 6,808 individuals accused of category one crimes were transferred to the gacaca courts under the amended genocide law in $2008 .{ }^{17}$ And this is why as one survivor puts it, "when I look out my window in the morning, I see the men who raped me, freely walking on their way to work." 18 And this is almost certainly why, while each survivor's testimonial [contained in The Men Who Killed $\mathrm{Me}$ ] is incomparable, one similarity is that they believe justice is not served. Of course I understand from other readings that judicially the gacaca courts have in some ways ensured justice is served, despite the consistently unenthusiastic views articulated by survivors in [The Men Who Killed $\mathrm{Me}$. But now the words of survivors like Hyacintha Nirere haunt me. "I go to the gacaca courts, but I am more and more frightened to give my testimony when I see what happens to other survivors when they do so. They are intimidated, or, even worse, killed. I wonder why I should give my testimony, because the Interahamwe are being released. It seems that our testimonies in gacaca courts are more formalities than truly helpful." 19

The Men Who Killed Me unquestionably highlights the authority of survivors as shown in the previous student's comments, as well as in the following anonymous evaluation for the course:

I may forget a theory or who said what, but I will never ever forget the woman [from The Men Who Killed Me] who had been chained to a bed for three months and raped continuously by a dozen of her captors. Her words are seared into my psyche. Whether she's in the fields, or at home, or at market, she will never get the smell of semen out of her nostrils.

Many of the testimonies in The Men Who Killed Me are arguably even more unsettling and shocking. They give witness to the vituperative misogyny that contaminates so much of the modern world.

De Brouwer and Chu's work provides a candid and multifaceted discussion of sexual violence during the 1994 genocide, including its ruthlessness and methodical orchestration; the culture of pre-existing gender inequality that helped create an 
environment that maliciously targeted women; and the systematic propaganda, which contributed appreciably to encouraging sexual violence against Tutsi women, the public nature of the rapes, and the level of brutality. Moreover, the publication sheds light on the stigma rape victims face today. ${ }^{20}$

Regarding organized propaganda, The Men Who Killed Me documents how the Hutu "Ten Commandments," published in December 1990, focused-in part-on the sexuality of Tutsi women. For example, the first "commandment" describes Tutsi women as tools of their ethnic community, used to weaken and destroy Hutu men. Furthermore, students learn that newspapers, such as the publication responsible for originally circulating the "Ten Commandments," commonly featured cartoons that portrayed Tutsi women, and even the moderate Hutu Prime Minister Agathe Uwillingiyimana who was later assassinated, as sexual objects. ${ }^{21}$

Furthermore, the book details how men, primarily of Tutsi ethnicity, were sexually assaulted, often by the mutilation of their genitals, which were sometimes displayed in public; and that in some cases Tutsi boys and men were forced to rape Tutsi women or were forced by Hutu women to have sex with them. ${ }^{22}$

The Men Who Killed Me helps students who might otherwise object to the female-centered nature of the discussion of rape by not only including a testimonial from a man and giving voice to the sexual assaults men endured, but also because the women's testimonials are replete with examples of the horrors their loved ones suffered, including sons, husbands, fathers, and brothers.

As Françoise Mukeshimana describes how her brother was ordered to dig his own grave just prior to her being gang raped, one is left with the indelible impression that there is in all probability no completely female-centered discussion of genocide-as-rape:

[T] he Interahamwe hit my brother with a huge club and told him to look at his sister for the last time. As he looked at me, he begged them to kill me first, because he feared that I would die of pain. Instead, they continued to bash him, until he died looking into my eyes. The Interahamwe then proceeded to discuss how they would kill me. One of them argued that it would be a great mistake if they killed me without humiliating me first. He said that they should strip me naked and do to me all that they wanted. ${ }^{23}$

The Men Who Killed Me also documents legislative changes in post-genocide Rwanda (e.g., laws that guarantee girls and women the same rights as boys and men to inherit property), and responses by non-governmental organizations, the international community, and the ICTR. It contains a discussion of the UN Security Council Resolution $1820 .^{24}$

Finally, the publication provides an overview of the roots of violence in Rwanda, including the complex and bloody history between Tutsi and Hutu starting with the Belgian colonialists' arrival in 1916; the growing resentment among the Hutu about the special treatment of Tutsi over the years; and the effects of Rwandan independence from Belgium in 1962, including the forced exile of more than 700,000 Rwandan Tutsi to neighboring countries between 1959 and 1973. It brings to light the growing denial of what happened during the 100-day genocide and remarks on the resurgence of contemporary genocidal ideology in Rwanda and other countries.

Halima Bashir's Tears of the Desert: A Memoir of Survival in Darfur (2008) ${ }^{25}$ also proves beneficial in making the subject more accessible to students and is an effective way to highlight the authority of survivors. Bashir was born in Darfur, and was raised in a loving family that was part of the black African Zaghawa tribe. In an 
unusual opportunity for a girl of her village, she attended junior and secondary school. Bashir even went on to study medicine, becoming her tribe's first trained doctor. By the time she had started to practice medicine, the Janjaweed had begun attacking black Africans in Darfur with the support of the local Sudanese government. Her willingness to treat those rebelling against the government and the Janjaweed got her dangerously noticed.

In January 2004, the militia attacked a remote school and gang-raped forty-two schoolgirls. Bashir was the only source of help in the neighboring one-room medical clinic. When she bravely spoke out regarding the atrocities, she was arrested by the secret police, interrogated, tortured, and raped. She escaped to her home village, but the violence followed her there, and her father and other relatives were killed in reprisal. Bashir was forced to flee Sudan in 2005 to seek a tenuous asylum in Britain.

Students are fond of referring to Bashir's story. They report that her memoir helps them understand how sexual violence begins and how, when unchecked, it can become rape-as-genocide. Students also value the historical background Bashir provides that assists in their understanding of the violence that overwhelms Darfur. They especially appreciate the epilogue regarding the history and causes of the current situation in Darfur.

An excerpt from a student's exam illustrates the first point, how sexual violence becomes rape-as-genocide:

Rape as a weapon of genocide is destructive to their person, their ethnic bonds, and to their physical health. I recognize that mass rape can destroy a substantial part of a group and therefore constitutes genocide. Prosecuting the rapes in Darfur, for example, as crimes against humanity would get at the crime's gravity. However, when all's said and done, genocide is a whole other order of destruction. And it is clear that thousands of women and girls are attacked by rapists as a means of destroying their ethnic group.

As it relates to the usefulness of the historical background provided by Bashir, a student-via e-mail-remarks,

I'm confessing my ignorance here but one thing I hadn't really realized [prior to reading Tears of the Desert] was the involvement of the British. It reminds me of the Belgians in Rwanda. By installing the Arabs to govern Sudan they helped create the very atmosphere in which this conflict would sooner or later ignite. Bashir states: "My father glanced at me, his eyes glinting. 'But you know the worst thing the British did? The very worst? When they left they gave all the power to the Arab tribes. They handed power to the Arabs. Now that's the sort of things you should be learning at school." "26

\section{Sensitizing, Not Traumatizing}

It should be noted that students report that The Men Who Killed Me and Tears of the Desert are particularly graphic. As a guiding principle and in pursuit of what Donald Schwartz (1990) calls "sensitizing not traumatizing," 27 I offer from the outset alternative ways of meeting the course requirements. Correspondingly, the United States Holocaust Memorial Museum's guidelines for teaching read as follows: "Students are essentially a 'captive audience' ... a basic trust [is] the obligation of the teacher to provide a 'safe' learning environment... Try to select images and texts that do not 
exploit the students' emotional vulnerability or that might be construed as disrespectful of the victims themselves." 28

Despite the option of replacing The Men Who Killed Me and/or Tears of the Desert with other comparable (less graphic) readings, no student has yet made such a request. Instead, a typical response to unsettling accounts goes something like this: "If you feel uncomfortable when you read this material, that's good." Or as another student put it,

\begin{abstract}
Sometimes I deliberately stay away from books like [Tears of the Desert] because I know they will be difficult to read, but at the same time I think it's crucial for us to read these accounts so we can be more informed regarding the appalling things that are sadly still happening in the world today. I have friends who think genocide started and ended with the Holocaust. Besides, it's too easy to be complacent while watching the news about countries on the other side of the world, thinking that it doesn't involve us. But then the news, if it even reports on sexual violence as genocide, usually spotlights statistics. Reading Tears of the Desert, and getting to know Halima [Bashir] and her family through the pages of the book, genuinely put a human face on the tragedy occurring in Darfur.
\end{abstract}

The same considerations regarding "sensitizing not traumatizing" students arise regarding documentaries. However, as with The Men Who Killed Me and Tears of the Desert no student has yet requested a less graphic substitution when it comes to films. In fact, when students are absent from class, and consequently miss a viewing, they appear to go out of their way to locate the documentary (e.g., request my copy, inquire into where they might locate it on online, or rent it).

\title{
Documentaries: G-d Sleeps in Rwanda, Mothers Courage, Thriving Survivors, and The Greatest Silence: Rape in the Congo
}

Films are a good way "to highlight the validity of life outside ... textbooks." 29 Like The Men Who Killed Me and Tears of the Desert, the documentaries G-d Sleeps in Rwanda (2005), ${ }^{30}$ Mothers Courage, Thriving Survivors (2005), ${ }^{31}$ and The Greatest Silence: Rape in the Congo (2007) ${ }^{32}$ redirect students' attention to the tens of thousands of girls and women who are victims of genocide.

In G-d Sleeps in Rwanda, the filmmakers chronicle the genocide's impact on five women. Each lost many, if not all family members, during the genocide. Similarly, Mothers Courage, Thriving Survivors offers testimonies from women survivors of the 1994 genocide. As is the case in G-d Sleeps in Rwanda, it chronicles women struggling to rebuild their lives and their country. ${ }^{33}$

Writing via e-mail, a student reflects on $G$-d Sleeps in Rwanda, illustrating its value as an educational tool:

$[\mathrm{H}]$ ow incredibly inspiring I found $G-d$ Sleeps in Rwanda. Based on the subject matter, I assumed it would be terribly hard to watch, and some parts certainly were. But I was so incredibly moved by the strength and ability of the women to persevere in the face of so much violence and repeated devastating attacks. I kept thinking to myself, "Don't ever, ever underestimate women." I felt incredibly proud to be a part of such an extraordinary gender. It is a staggering statistic that $70 \%$ of the Rwandan population is now female, but also incredible that so many women have risen to the occasion to become political leaders, heads of households (some at such a young age), and are able to accomplish such labor-intensive jobs (not that I ever doubted women could do such things!!!). 
The student continues:

In some of the readings, the sexual violence perpetrated against these women seems to be understood to be the equivalent of killing them through psychological damage, physical torture, or damage to their reproductive system, and through the damage it creates in their families and communities. And though all of these disgusting intended consequences are true, the point is many of these women are still not dead. And are astoundingly able to create solidarity and to rebuild their communities and families. It is TRULY remarkable and inspirational to see some positive things come from such horrible events. It is really important to focus on such things.... I think [G-d Sleeps in Rwanda] has given me yet another perspective in a horrific, yet direly important topic.

"The idea that sexual violence in Rwanda was not merely the product of a few misogynist Hutu extremists, but a thorough-going policy of the state and its agents leaves me speechless," another student writes in reaction to Mothers Courage, Thriving Survivors. "That stories like Athanasie Mukarwego's, who was raped while her four children were sequestered in the next room, would not attract enough interest or compassion to make powerful people and nations take immediate action, makes me both distressed and furious."

As a final example of the pedagogical power of film, The Greatest Silence: Rape in the Congo presents evidence that rape and sexual torture of girls and women in the Congo is meticulously carried out to create and prolong an atmosphere of political and economic insecurity in a country where valuable natural resources are exploited by profiteers.

Corresponding via e-mail, a number of students describe their reactions to the film: "After watching [The Greatest Silence: Rape in the Congo] I decided to protest China's aid to the repressive regime in Darfur, part of what is destabilizing all of central Africa. It makes me feel better to know that I'm doing something." A second student remarks, "It is utterly incomprehensible that there is so little media coverage on this.... Every day we are suffocated by endless entertainment 'news,' and then zero about the Congo." A third student writes:

All this in a world where slogans like "women's rights" appear frequently in news accounts and are echoed in the best lecture halls universities have to offer. Shame that more people can't see this [film], isn't it? Meanwhile some brainless horror flick, which glorifies rape, or uses rape to shock and sell tickets, sells out three weeks in a row [at the local theater].

\section{Commentary by Eve Ensler}

Two commentaries, written by Eve Ensler and published in 2007 by The Washington Post and Glamour magazine, are frequently mentioned by students during discussions of rape-as-genocide. While one can appreciate that giving commentaries to students for discussion makes sense, commentary alone is not sufficiently academic. It does, however, make the subject matter more accessible.

Ensler's work, in combination with a scholarly piece like Reva N. Adler, Cyanne E. Loyle, and Judith Globerman (2007), ${ }^{34}$ helps students make links between the social position of women in Congo, the life of women prior to the 100-day Rwanda genocide, and the ultimate devaluation of girls and women during and after genocide. An excerpt from an exam illustrates the success of this approach: 
According to Adler, Loyle, and Globerman (2007), under Rwandan law, prior to 1994, women were banned from inheriting property, entering into any legal agreement, or even opening a bank account without the permission of their husbands; very few held positions of power inside government. ${ }^{35}$ In Congo, Ensler (2007) found that for at least one man it was more important to protect gorillas than women.... ${ }^{36}$ Social constructions of masculinity and systematic sexism are indispensable to understanding violence against women-sexual and otherwise. In times of peace, it is no different.

A second example of the efficacy of Ensler's commentary is in its ability to encourage students to think analytically about the UN Convention on Genocide. "Ensler (2007) unmistakably links rape in the Congo to at least four of the five elements of genocide outlined in the UN Convention," argues one student. Similarly, a student referring to Samantha Power (2002) and then Ensler (2007) remarks,

According to the UN Convention, genocide includes killing members of the group, causing serious bodily or mental harm to members of the group, deliberately inflicting on the group conditions of life calculated to bring about its physical destruction in whole or in part, imposing measures intended to prevent births within the group, and forcibly transferring children of one group to another group. ${ }^{37}$ Rape clearly fits into each of the requirements for genocide. Mass rape results in the death of many women, including as a result of HIV/AIDS. It causes both mental and physical harm to the survivors, including vesicovaginal and rectovaginal fistula. It renders survivors unable to bear children, which stifles the next generation. It results in diluting the ethnicity of the victim's children, which serves to damage her community. "Clearly these rapes are not done to satisfy any sexual desire but to destroy the soul. The whole family and community are broken." 38

A third advantage of Ensler's commentary lies in its capacity to encourage students to think critically, even about seemingly positive steps to combat sexual violence. For example, a year after the adoption of Resolution 1820, the UN dubbed Congo the worst place on earth to be female; and while sources like The Men Who Killed Me offer an overview of Resolution 1820, Ensler (2009) offers a more critical appraisal:

Resolution 1820 must be enforced with seriousness by the Security Council and the secretary general. Arrests need to be made immediately of known rapists and war criminals at the highest levels. The United Nations must stop supporting military actions, because they are doomed in Congo. And the root economic causes of the war need to be addressed with the leaders of countries in Africa's Great Lakes region who commit violence to reap benefits from Congo's minerals, as well as their Western corporate partners. They, too, are liable for these atrocities.... The women of eastern Congo are enduring their 12th year of sexual terrorism. The girl children born of rape are now being raped. What will it take for the United Nations to finally do something meaningful to stop the violence? The women are waiting. ${ }^{39}$

Though an arguably cursory summary of the situation in Congo, Ensler's piece cited above, used in combination with scholarly materials, effectively encourages critical thinking and leads to theoretically sophisticated analysis.

Last, a recurring theme in students' comments relates to Ensler's description of women lined up at her door before breakfast wanting to talk. ${ }^{40}$ "There were actual lineups of women wanting to be heard!" wrote one student in typical fashion. Students consistently conclude, as does Ensler, that the deepest wounds for survivors is the sense that they have been forgotten, that they are invisible, and that 
their pain has no meaning. The simple act of listening to survivors has a profound impact on students and their education.

\section{Conclusions}

Despite the sophisticated and theoretically informed reflections typically provided by students, understanding the unrelenting brutality that is genocide lies outside their experience for the majority of them. Furthermore, statistics like "500,000 raped" are impossible to grasp. First-hand accounts promote solidarity with victims and a deeper understanding of rape-as-genocide, including its lingering effects in postgenocide societies.

How effective might the approach described here be in other contexts, in other institutions, and with other students? Committed to multi-disciplinary social justice research, the public institutions in Canada where I have taught are richly diverse communities. A large number of undergraduates are immigrants or first-generation students. At least a half-dozen of my students are survivors of genocide and war. My students also tend to be a little older than traditional college age, which may mean they are more likely to possess the sensibilities required to address these sensitive issues. Finally, the course is offered to senior undergraduates. These factors may help explain the incredibly articulate and well-written responses I typically receive.

The implications here go beyond any one course however. Ignoring sexual violence, either by excluding it from the curriculum or by mentioning it merely in passing, has significance. In such cases, educators inadvertently send the message that rape-as-genocide is not worthy of our attention. Thus, we contribute to "the greatest silence." Furthermore, neglect of rape-as-genocide adds to the normalization of rape (in any context).

In the end, the choice of pedagogical approach is unavoidably accompanied by a "taking of sides." I prefer to include first-hand accounts because no one person can give genuine voice to victims and survivors of rape-as-genocide.

\section{Acknowledgments}

This paper is dedicated to Tessa M. Blaikie, Daniel Church, Charles Corey, Brendan M. Forsyth, Nicole R. Gordon, Enisa Hazirovic, Natalia T. Ilyniak, Brent T. Maunder, Julia Peristerakis, and Rhys J. Williams, current and former sociology undergraduate students at the University of Winnipeg who have studied genocide with me, some of whom have devoted their honors papers to the topic, and all of whom refuse to turn away from evil, even if it is unfathomable.

\section{Notes}

1. Andrew Woolford, "Making Genocide Unthinkable: Three Guidelines for a Critical Criminology of Genocide," Critical Criminology 14, no. 1 (2006): 89.

2. Anne-Marie de Brouwer and Sandra Chu, eds., The Men Who Killed Me: Rwandan Survivors of Sexual Violence (Vancouver: Douglas \& McIntyre, 2009), 150-51.

3. See, for example, Julie Mertus, "Truth in a Box: The Limits of Justice Through Judicial Mechanisms," in The Politics of Memory: Truth, Healing and Social Justice, ed. If Amadiume and Abdullahi A. An-Na'im (London: Zed Books, 2000); Julie Mertus, "The Politics of Memory and International Trials for Wartime Rape," in Political Transition: Politics and Cultures, ed. Paul Gready (London: Pluto, 2003); Michelle Staggs Kelsall and Shanee Stepakoff, "When We Wanted to Talk About Rape': Silencing Sexual Violence at the Special Court for Sierra Leone," International Journal of Transitional Justice 1 (2007): 355-74. 
4. There is a substantial literature one might draw on from the perspective of perpetrators including Scott Straus, The Order of Genocide: Race, Power, and War in Rwanda (Ithaca, NY: Cornell University Press, 2006); Alexander Laban Hinton, Why Did They Kill? Cambodia in the Shadow of Genocide (Berkeley: University of California Press, 2005); Charles Mironko, "Igitero: Means and Motive in the Rwandan Genocide," Journal of Genocide Research 6 (2004): 47-60; Christopher Browning, "German Memory, Judicial Interrogation, and Historical Reconstruction: Writing Perpetrator History from Postwar Testimony," in Probing the Limits of Representation: Nazism and the "Final Solution, ed. S. Friedländer (Cambridge, MA: Harvard University Press, 2002), 407.

5. Ervin Staub, The Roots of Evil: The Origins of Genocide and Other Group Violence (Cambridge: Cambridge University Press, 1989), 29.

6. Daniel Jonah Goldhagen in Hitler's Willing Executioners: Ordinary Germans and the Holocaust (New York: Knopf, 1996), argues it was not "ordinary men" but "ordinary Germans" who willingly engaged in genocidal acts, because they had internalized a cultural model of extreme anti-Semitism. Students are required to critique Goldhagen's interpretation of the historical record. In pursuit of this goal, they also read Christopher Browning's alternative explanation of the German Police Battalion court transcripts, in Ordinary Men: Reserve Police Battalion 101 and the Final Solution in Poland (New York: Harper Collins, 1993, 1998)—the same transcripts on which Goldhagen relies in making his argument for a peculiarity German "eliminationist anti-Semitism."

The debate between Goldhagen and Browning is of great importance. As Wayne Morrison notes,

In Browning's account the reader must always consider a reflexive question: "if I was in that position can I really be sure I would not have participated?" ... If Goldhagen is correct there are no general lessons to learn from the Holocaust ... But if Browning is correct we are dealing with a general potentiality.

Wayne Morrison, “'Reflections with Memories': Everyday Photography Capturing Genocide," Theoretical Criminology 8 (2004): 341-58, 345.

7. See for example, Robyn Charli Carpenter, "Surfacing Children: Limitations of Genocidal Rape Discourse," Human Rights Quarterly 22 (2000): 428-29.

8. Academically sophisticated sources include Beverly Allen, Rape Warfare: The Hidden Genocide in Bosnia-Herzegovina and Croatia (Minneapolis: University of Minnesota Press, 1996); Claudia Card, "Rape as a Weapon of War," Hypatia 11 (1996): 4-18; Iris Chang, The Rape of Nanking: The Forgotten Holocaust of World War II (New York: Basic Books, 1997); Shiva Eftekhari, Struggling to Survive: Barriers to Justice for Rape Victims in Rwanda (New York: Human Rights Watch, 2004); Karen Engle, "Feminism and Its (Dis)Contents: Criminalizing Wartime Rape in Bosnia and Herzegovina," The American Journal of International Law 99 (2005): 778-816; Nancy Farwell "War Rape: New Conceptualizations and Responses," Affilia 19 (2004): 389-403; Judith Gardam, "Women and the Law of Armed Conflict: Why the Silence?" The International and Comparative Law Quarterly 46 (1997): 55-80; Judith Gardam and Michelle J. Jarvis, Women, Armed Conflict and International Law (The Hague: Kluwer Law International, 2001); Richard J. Goldstone, "Prosecuting Rape as a War Crime," Case Western Reserve Journal of International Law 34 (2002): 277-86; Jennifer Green, "Uncovering Collective Rape: A Comparative Study of Political Sexual Violence," International Journal of Sociology 34 (2004): 97-116; Anna Hoglund, "Justice for Women in War? Feminist Ethics and Human Rights for Women," The Journal of the Britain and Ireland School of Feminist Theology 11 (2003): 346-61; Margaret A. Lyons, "Hearing the Cry Without Answering the Call: Rape, Genocide, and the Rwandan Tribunal," Syracuse Journal of International Law and Commerce 28 (2001): 99-124; Catherine Niarchos, "Women, War, and Rape: Challenges Facing the International Tribunal for the Former Yugoslavia," Human Rights Quarterly 17 (1995): 649-90; Binaifer Nowrojee, Shattered Lives: Sexual Violence during the Rwandan Genocide and its Aftermath (New York: Human Rights Watch, 1996); 
Sherrie L. Russell-Brown, "Rape as an Act of Genocide," Berkeley Journal of International Law 21 (2003): 350-74; Zainab Salbi, The Other Side of War: Women's Stories of Survival and Hope, ed. L. Becklund (Washington, DC: National Geographic Society, 2006); Todd Salzman, “'Rape Camps,' Forced Impregnation, and Ethnic Cleansing: Religious, Cultural, and Ethical Responses to Rape Victims in the Former Yugoslavia," in War's Dirty Secret: Rape, Prostitution, and Other Crimes Against Women, ed. A.L. Barstow (Cleveland: The Pilgrim Press, 2000); Leslie Shanks and Michael J. Schull, "Rape in War: The Humanitarian Response," CMAJ: Canadian Medical Association Journal 163 (2000): 1152-57; Lisa Sharlach, "Gender and Genocide in Rwanda: Women as Agents and Objects of Genocide," Journal of Genocide Research 1 (1999): 387-99; Inger Skjelsbaek, "Sexual Violence and War: Mapping Out a Complex Relationship," European Journal of International Relations 7 (2000): 211-38; Dorothy Q. Thomas and Regan E. Ralph, "Rape in War: Challenging the Tradition of Impunity," SAIS Review Spring/Winter (1994): 81-98; Jennifer Turpin, "Barbie in the War Zone," Social Alternatives 22 (2003): 5-7; Justin Wagner, "The Systematic Use of Rape as a Tool of War in Darfur: A Blueprint for International War Crimes Prosecutions," Georgetown Journal Of International Law 37 (2005): 193-243; Human Rights Watch, "Sexual Violence and its Consequences among Displaced Persons in Darfur and Chad," Human Rights Watch, 2005, http://www.cmi.no/sudan/doc/?id=1069 (accessed 01 July 2010).

9. Allison Ruby Reid-Cunningham, "Rape as a Weapon of Genocide," Genocide Studies and Prevention 3, no. 3 (December 2008): 279-96.

10. Kelly Dawn Askin, "Holding Leaders Accountable in the International Criminal Court (ICC) for Gender Crimes Committed in Darfur," Genocide Studies and Prevention 1, no. 1 (2006): 13-28.

11. Anne-Marie de Brouwer, "Supranational Criminal Prosecution of Sexual Violence: The ICC and the Practice of the ICTY and the ICTR," Intersentia (2005): 13-14.

12. Alexandra Stiglmayer, ed., Mass Rape: The War against Women in Bosnia-Herzegovina, (Lincoln: University of Nebraska Press, 1994), 197.

13. Adam Jones, Gendercide and Genocide (Nashville, TN: Vanderbilt University Press, 2004).

14. Rhonda Copeland, "Surfacing Gender: Reconceptualizing Crimes against Women in Time of War," in Mass Rape: The War against Women in Bosnia-Herzegovina, ed. Alexandra Stiglmayer (Lincoln: University of Nebraska Press, 1994), 197-98.

15. As of May 2010, The Men Who Killed Me is also available in Dutch from Nijmegen, Oisterwijk: Wolf Legal Publishers.

16. The man-Faustin Kayihura-was thirteen years old in 1994.

17. Anne-Marie de Brouwer and Sandra Chu, eds., The Men Who Killed Me: Rwandan Survivors of Sexual Violence (Vancouver: Douglas \& McIntyre, 2009), 150-51.

18. Ibid., 2.

19. Ibid., 123.

20. Ibid., 11-19.

21. Ibid., 15.

22. Ibid., 14-15.

23. Ibid., 101.

24. Ibid., 145-58.

25. Halima Bashir, Tears of the Desert: A Memoir of Survival in Darfur (New York: One World/Ballantine, 2008).

26. Ibid., 100.

27. Donald Schwartz, “'Who Will Tell Them After We're Gone?': Reflections on Teaching the Holocaust," The History Teacher 23 (1990): 95-110.

28. For more guidelines, visit United States Holocaust Memorial Museum, "Guidelines for Teaching about the Holocaust," http://www.ushmm.org/education/foreducators/ (accessed 01 July 2010). 
29. David A. Long, "Sociology and a Pedagogy for Liberation: Cultivating a Dialogue of Discernment in Our Classrooms," Teaching Sociology 23 (1995): 321-30.

30. G-d Sleeps in Rwanda, prod. Kimberlee Acquaro and Stacy Sherman, 28 min., Women Make Movies, 2004, DVD.

31. Mothers Courage, Thriving Survivors, dir. Léo Kalinda, 52 min., National Film Board of Canada, 2005, DVD.

32. The Greatest Silence: Rape in the Congo, prod./dir. Lisa F. Jackson, 1hr., 16 min., Jackson Films Inc., 2007, DVD.

33. Another film that is effective in giving voice to women survivors in Rwanda is The Diary of Immaculée, dir. Peter LeDonne, 38 min., New Jersey Shore LLC, 2006, DVD. Immaculée Ilibagiza recounts how she and seven other females found sanctuary in a small bathroom in the home of an Episcopalian Hutu minister during the genocide. For ninety-one days the girls and women lived in the bathroom, in fear of Hutu extremists. Excerpts from Immaculee Ilibagiza's Left to Tell: Discovering G-d Amidst the Rwandan Holocaust (Hay House, 2007), a first-hand account of how she survived the genocide, have proved to be equally effective.

34. Reva N. Adler, Cyanne E. Loyle, and Judith Globerman, "A Calamity in the Neighborhood: Women's Participation in the Rwanda Genocide," Genocide Studies and Prevention 2, no. 3 (November 2007): 209-34.

35. Ibid., 216.

36. Eve Ensler, "Women Left for Dead-and the Man Who's Saving Them," Glamour (2007), http://www.glamour.com/magazine/2007/08/rape-in-the-congo?currentPage=1 (accessed 01 July 2010).

37. Samantha Power, A Problem from Hell: America and the Age of Genocide (New York: Basic Books, 2002).

38. Ensler, "Women Left for Dead."

39. Eve Ensler, “A Broken U.N. Promise in Congo," http://www.washingtonpost.com/wpdyn/ content/article/2009/06/29/AR2009062903456.html (accessed 01 July 2010).

40. Ensler, "Women Left for Dead." 